Kendall, M. G., and Smith, B. B. Tables of random sampling numbers. Cambridge, England, 1939.

Kravtchenko, J. See Villat, H.

LEwIS, J. V. The existence of solutions to Lagrange problems for multiple integrals. Diss., California, 1942.

Lines Escard6, E. Aplicaciones de la teoría de redes regulares al estudio de las funciones cuasiperi6dicas. Madrid, 1943.

Lonseth, A. T. The problem of Plateau in hyperbolic space. Diss., California, 1939.

Mathematical tables project. Tables of fractional powers. New York, 1946.

MAUCH, M. E. Extensions of Waring's theorem on seventh powers. Diss., Chicago, 1938.

Minorsky, N. Introduction to non-linear mechanics. Part 3, Washington, 1946.

NAvarro Borras, F. Conferencias sobre la teoría de las ecuaciones integrales (lineales y no-lineales). Madrid, 1942.

OldENBURGER, R. Composition and rank of $n$-way matrices and multilinear forms. Diss., Chicago, 1934.

Perlis, S. Maximal orders in rational cyclic algebras of composite degree. Diss., Chicago, 1938.

Prtcher, A. D. Interrelations of eight fundamental properties of classes of functions. Diss., Chicago, 1910.

Rey PAstor, J. Los ultimos teoremas geometricos de Poincaré y sus aplicaciones. Buenos Aires, 1945.

RIos, S. La prolongacion analitica de la integral de Dirichlet-Stieltjes. Madrid, 1944.

Sanches Perez, J. A. La aritmetica en Babilonia y Egipto. Diss., Madrid, 1943.

Schoenfeld, L. A transformation formula in the theory of partitions. Diss., Pennsylvania, 1944.

SchwarTZ, L. Etude des sommes d'exponentielles réelles. Paris, 1943.

SCHweItZER, A. R. Les idées directrices de la logique génétique des mathématiques. Diss., Chicago, 1916.

SimoN, W. G. On the solution of certain types of linear differential equations in infinitely many variables. Diss., Chicago, 1918.

Sмiтн, A. W. The symbolic treatment of differential geometry. Diss., Chicago, 1904.

Smith, B. B. See Kendall, M. G.

SPEISER, A. Festschrift zum 60. geburtstag von. Zurich, 1945.

SzNYTER, M. H. The hypersurface of the second degree in four-dimensional space. Diss., California, 1918.

Teubner, B. G. Verlag auf dem gebiete der mathematik und ihrer anwendungen, mit anhang: Mechanik. Leipzig, n.d.

Valiron, G. Equations fonctionnelles. Applications. Paris, 1945.

Villat, H. Leçons sur les fluides visqueux. Ed. by J. Kravtchenko. Paris, 1943.

WEIL, A. L'intégration dans les groupes topologiques et ses applications. Paris, 1940.

WeyL, $H$. The classical groups, their invariants and representations. $2 d$ ed., Princeton, 1946.

Wilks, S. S. Mathematical statistics. Princeton, 1944.

WoLFE, H. E. Introduction to non-Euclidean geometry. New York, 1945.

\title{
CORRECTIONS TO BE MADE IN CATALOGUE OF THE LIBRARY ${ }^{1}$
}

p. 50. Replace "Bovieri-Lapierre" with "Bovier-Lapierre."

p. 67. Replace entry for Durfee, W. F. with "Factor table for the sixteenth million. (Manuscript) n.p., n.d."

p. 77. Delete entry for Föppl, L.

p. 83. Replace second entry for Goldschmidt, L. with "Über den satz Eulers: $(1-x)\left(1-x^{2}\right)\left(1-x^{3}\right) \cdots=\sum_{0}^{\infty}(-1)^{n} x^{\left(3 n^{2 \pm}\right) / 2}$. Gotha, 1892 .

p. 112. Delete entry for Lekarski, I. C.

p. 140. Replace entry for Roberts, $H$. $\dot{L}$. with "On the transformation group $p, q, r$, $x p, y q, z r, x^{2} p, y^{2} q, z^{2} r$. Diss., Virginia, 1899."

p. 165. Entry under Wassiljef, A. should be moved to p. 162 as a second item under the name Vasil'ev, A.

1 Bull. Amer. Math. Soc. v. 52 (1946) n5, part 2. 